\title{
HARVESTING OF MEDICINAL PLANTS IN THE FOREST OF CENTRAL INDIA AND ITS IMPACT ON QUALITY OF RAW MATERIALS: A CASE OF NAGPUR DISTRICT, INDIA
}

\author{
Manish Mishra, P. C. Kotwal and Chandan Prasad \\ Faculty of Ecosystem Management and Technical Forestry \\ Indian Institute of Forest Management \\ Post Box: 357, Nehru Nagar, Bhopal (M.P.), India
}

\begin{abstract}
Adulteration and substitutions are frequent in raw material trade of medicinal plants. Several studies have been done for a number of important crude drug materials to distinguish the genuine material from adulterant. The efficient way to determine adulteration is through morphological and organoleptic studies. The objective of this study is to find out current harvesting methods, malpractices adopted by various stakeholders and ocular analysis of market samples, impacting quality of raw (dry) produce of selected species in market of Nagpur. In the natural forests Baibirang (Embelia ribes Burm.), Safed musli (mixed tubers of Chlorophytum borivilianum Baker, $C$. tuberosum Baker.), and Aonla (Emblica officinalis Gaertn.) were collected just after the rains at unripe stage. The ocular observations of the market sample of Aonla, Baibirang fruits, Safed musli tubers indicate that mixing of old and diseased parts of same species and other adulterants is rampant in the local market. Laboratory analysis shows that in one kilogram of market sample, more than $20 \%$ raw material was found adulterated in all the selected species except Bach (Acorus calamus L.). Most of the selected plants were found adulterated, both intentionally and unintentionally. Major reasons for poor quality are unripe harvesting, mixing of inferior and cheap plant parts, mis-identification of species, non-availability of plant parts in required quantity, etc.
\end{abstract}

Key words: Adulteration, quality, medicinal plants, harvesting, malpractices.

\section{INTRODUCTION}

The increase in demand of medicinal plants for the commercial herbal medicine led to the indiscriminate and unscientific collection without any consideration for quality of the material collected. In many cases the immature extraction of fruits, roots, tubers, etc. has drastically reduced the quality as well as quantity of the raw product to below critical level. Many studies on different species have confirmed the same. Mishra (2000), Mishra et al. (2003), Mishra and Kotwal (2003, 2004, 2007) and Prasad et al. (2002) conducted a number of studies on sustainable harvesting, value addition, processing of some important medicinal plants like Aonla (Emblica officinalis Gaertn.), Achar (Buchanania lanzan Spreng.), Safed musli (Chlorophytum spp.), Malkangni (Celastrus paniculatus Willd.), Sarpgandha (Rauvolfia serpentina (L.) Benth. ex Kurz), Satawar (Asparagus racemosus Willd.), in the tropical dry deciduous forests of central India. They reported that due to immature extraction the yield per plant and quality of raw material of these species is declining in the natural forests. 
According to Handa (2004), the majority of the medicinal and aromatic plants used by the herbal drug industry come from wild collection. Approximately $90 \%$ of India's medicinal plant supply to international market is from wild stocks. A treatise published two centuries ago in 1820 on adulteration in food and culinary materials is a proof of this practice as an age old one (Accum 1820).Due to adulteration, faith in herbal drugs has declined (Gupta et al. 2003). Adulteration in market samples is one of the greatest drawbacks in promotion of herbal products (Dubey et al. 2004). Many researchers have contributed in checking adulterations and authenticating them (Tiwari 1991, Vasudevan et al. 1983, Sunita, G. 1992, Uniyal and Joshi 1993, Sarin 1996, Saraswathy 2001, Gupta et al. 2003).

The raw material used by drug and Ayurvedic industry is generally procured through market channels and are sometimes found adulterated. The efficient way to determine adulteration is through morphological and organoleptic studies (Sarin 2003). At present most herbal raw materials are still harvested or wild crafted under completely uncontrollable conditions (Lange 2004). Indian Ayurvedic industries generally face the problem of adulteration and substitution at raw material stage. Rawat et al. (1996) and Rawat (2005) observed that in herbal markets of the country, sometimes not only the various species of particular genus but entirely different taxa are being sold under the same vernacular name (i.e., in the name of Daru haridra, Chitrak, Vidarikand, Sariva and Ratanjot, two or more different plant species are being sold). The means of adulteration and substitution may be deliberate or sometimes unintentional. Such adulteration and substitution lead to poor quality of raw material in the market. Sometimes in place of the official drug, substituted products which have similar appearance to that of official drugs are deliberately mixed. This generally happen when official drugs are in scarcity (Sunita 1992). Broadly, adulteration is considered as an intentional malpractice. Mitra and Kannan (2007) reported that in raw material trade unintentional adulteration also exists.

The aim of the present study is to find out current harvesting methods and other malpractices impacting quality of raw (dry) produce of selected species. Analysis of market sample was done to find out adulterants present in the market samples. The forest survey and market sample collection was done during 2007-08, as and when based on the season/availability of species in the natural forests of Nagpur district.

\section{MATERIALS AND METHODS}

\section{Species selected for study}

The following commercially traded species were selected for the present study:

Ashwagandha (Withania somnifera Burm.), Aonla (Emblica officinalis Geartn.); Safed musli (Chlorophytum spp. Baker.); Bach (Acorus calamus L.) ; Baibidang (Embelia ribes Burm.).

\section{Survey of primary collectors}

A field survey of Nagpur forest division was done with the help of semi structured questionnaire. Information related to harvesting of selected species were collected during the time of harvesting of each species and according to their availability in the natural forest conditions. Method adopted by primary collectors, villagers, etc. to harvest fruits, roots, tuber, etc. from the natural forest in Nagpur was closely examined during the time of harvesting. A total of 5 forest ranges and 5 villages in each range were selected for collecting data. Persons involved ( $15 \%$ households) in each village (total 25 villages) in collecting roots/tubers, 
fruits, etc. from the natural forests were interviewed about the time and method of harvesting, tools used, etc.

\section{Survey of shopkeepers/traders}

These were surveyed to get an idea of quality of raw material currently in use, the substituted species, their name, different malpractices adopted by the shopkeepers, traders in the local market. For this purpose beside personal interviews through questionnaires, personal interaction with the local traders, wholesalers, retailers, etc. was done. A total of 6 traders $(50 \%)$, suppliers of selected species were surveyed, with the help of pre designed questionnaire.

\section{Ocular (Organoleptic) analysis of raw (dry) samples}

Raw material samples were collected from two different sources:

i. Natural forests: Fresh sample of roots, fruits, etc. were collected from the adjoining natural forests of Nagpur circle. Project team visited natural forest at the time of maturation (fruits, roots) of each selected species. More than one kilogram samples were harvested from field site and dried under laboratory conditions. The dried material weighing one kilogram each was analyzed using magnifying lens and weighing machine, etc.

ii. Trader's sample: Market samples (raw) of selected medicinal plant were collected from six local traders of the Nagpur market out of the total 12 traders. The traders located in different parts of Nagpur city were asked to provide good quality and fresh samples (dry) of selected medicinal plants. One kilogram raw material (dry) of each selected species was procured and than analyzed using morphological parameters. Traders were asked to provide fresh sample of each species based on the availability in the forest. Average values of 6 traders were given in the tables. The identification and documentation of adulterated species was done under laboratory conditions with the help of taxonomist, and consulting flora. Help from Ayurvedic practitioners and experts were also taken during identification of adulterants.

\section{RESULTS}

Data presented in Table 1 indicate that almost all selected species have been collected from natural forests in Nagpur at an early or immature stage, i.e., Aonla in October as against December, when it reaches maturity. Safed Musli was collected in October as against its maturity time (Nov-Dec.); Baibidang in Jan.-Feb. as against Feb.-Mar., when it reaches maturity. However, Ashwagandha roots were collected from farmer's field (cultivated) after the maturity.

Aonla fruits were collected destructively by lopping, pollarding of branches in the natural forest of Nagpur district. Mostly axe and bamboo poles were used for collecting fruits. In case of Musli and Bach whole tubers were uprooted manually from the ground with the help of locally made Kudali or small pick axes. In case of Ashwagandha, roots were collected using agricultural equipments used in agri-fields.

The data depicted in Table 2 show ocular observation analysis of samples collected from natural forest and traders of Nagpur market. The samples collected from natural forest (after maturation) did not show significant difference among various parameters studied. However, Forest (master) sample contains more than $95 \% \mathrm{~g}$ good quality sample in all the selected species. However, very few amounts (5-8\%) of soil, chaff matter $(10-30 \mathrm{~g} / \mathrm{kg})$ and infected parts were recorded in the samples collected from natural forest. 
Table 1. Harvesting pattern of fruit, tubers of selected medicinal plants in the natural forests of Nagpur district.

\begin{tabular}{|c|c|c|c|c|c|}
\hline Medicinal plant & $\begin{array}{c}\text { Natural/ } \\
\text { Cultivated }\end{array}$ & Maturity time & $\begin{array}{c}\text { Present } \\
\text { harvesting time }\end{array}$ & $\begin{array}{l}\text { Method of } \\
\text { harvesting }\end{array}$ & Tools used \\
\hline Ashwagandha (Withania somnifera) & Cultivated & $\begin{array}{l}\text { Not found in } \\
\text { Natural Forest }\end{array}$ & Feb-March & $\begin{array}{l}\text { Uprooting } \\
\text { whole plant }\end{array}$ & Big Pix axe \\
\hline Aonla (Emblica officinalis) & Natural & Dec. & October & $\begin{array}{l}\text { Lopping } \\
\text { branches }\end{array}$ & $\begin{array}{l}\text { Bamboo } \\
\text { stick, Axe }\end{array}$ \\
\hline Safed musli* (Cholophytum spp.) & Natural & Nov. & September & $\begin{array}{c}\text { Uprooting } \\
\text { whole plant }\end{array}$ & Small pix axe \\
\hline Bach (Acorus calamus) & Natural & Nov.-Dec. & September & $\begin{array}{l}\text { Uprooting } \\
\text { whole plant }\end{array}$ & By hand \\
\hline Baibidang (Embelia ribes) & Natural & December & Jan.-Feb. & $\begin{array}{c}\text { Hand } \\
\text { pricking }\end{array}$ & Hand, sickle \\
\hline
\end{tabular}

* Mixed tubers of Chlorophytum borivilianum, C. tuberosum

Table 2. Occular analysis of raw (dry) samples collected from natural forests and Nagpur market (avg. of one $\mathrm{kg}$ sample of each species).

\begin{tabular}{|c|c|c|c|c|c|}
\hline Species & $\begin{array}{l}\text { Sample } \\
\text { collected } \\
\text { from }\end{array}$ & $\begin{array}{c}\text { Best } \\
\text { quality } \\
\text { (g/kg) }\end{array}$ & $\begin{array}{c}\text { Infected by } \\
\text { fungus,insect } \\
(\mathrm{g} / \mathrm{kg})\end{array}$ & $\begin{array}{l}\text { Adulterant } \\
\text { species } \\
(\mathrm{g} / \mathrm{kg})\end{array}$ & $\begin{array}{c}\text { Chaff matter, soil, } \\
\text { seed, stone and sand } \\
(\mathrm{g} / \mathrm{kg})\end{array}$ \\
\hline \multirow[t]{3}{*}{ Ashwagandha (Withania somnifera) } & $\begin{array}{c}\text { Natural } \\
\text { Forest }\end{array}$ & 960.00 & 05.00 & 00.00 & 35.00 \\
\hline & Traders & 800.00 & 75.00 & 95.00 & 30.00 \\
\hline & & $(\mathrm{SE} \pm 0.95)$ & $(\mathrm{SE} \pm 0.42)$ & $(\mathrm{SE} \pm 0.88)$ & $(\mathrm{SE} \pm 0.22)$ \\
\hline \multirow[t]{3}{*}{ Aonla (Emblica officinalis) } & $\begin{array}{c}\text { Natural } \\
\text { Forest }\end{array}$ & 950.00 & 10.00 & 00.00 & 40.00 \\
\hline & Traders & 770.00 & 65.00 & 55.00 & 110.00 \\
\hline & & $(\mathrm{SE} \pm 1.03)$ & $(\mathrm{SE} \pm 0.35)$ & $(\mathrm{SE} \pm 0.22)$ & $(\mathrm{SE} \pm 0.69)$ \\
\hline \multirow[t]{3}{*}{ Safed musli* (Chorlophytum spp.) } & $\begin{array}{c}\text { Natural } \\
\text { Forest }\end{array}$ & 970.00 & 15.00 & 00.00 & 25.00 \\
\hline & Traders & 790.00 & 80.00 & 110.00 & 20.00 \\
\hline & & $(\mathrm{SE} \pm 0.77)$ & $(\mathrm{SE} \pm 0.44)$ & $(\mathrm{SE}(0.58)$ & $(\mathrm{SE}(0.17)$ \\
\hline \multirow[t]{3}{*}{ Bach (Acorus calamus) } & $\begin{array}{c}\text { Natural } \\
\text { Forest }\end{array}$ & 980.00 & 10.00 & 00.00 & 10.00 \\
\hline & Traders & 905.00 & 07.00 & 78.00 & 10.00 \\
\hline & & $(\mathrm{SE} \pm 0.31)$ & $(\mathrm{SE} \pm 0.02)$ & $(\mathrm{SE} \pm 0.62$ & $(\mathrm{SE} \pm 0.08)$ \\
\hline \multirow[t]{3}{*}{ Baibidang (Embelia ribes) } & $\begin{array}{c}\text { Natural } \\
\text { Forest }\end{array}$ & 985 & 05.00 & 00.00 & 10.00 \\
\hline & Traders & 750.00 & 70.00 & 100.00 & 80.00 \\
\hline & & $(\mathrm{SE} \pm 1.12)$ & $(\mathrm{SE} \pm 0.53)$ & $(\mathrm{SE} \pm 0.27)$ & $(\mathrm{SE} \pm 0.84)$ \\
\hline
\end{tabular}

* Mixed tubers of Chlorophytum borivilianum, C. tuberosum

Note 1. One kilogram samples (each selected species) were purchased from six traders. Average values of 06 traders were given

2. Both the samples collected from forest and local market were analyzed simultaneously under laboratory conditions. SE $=$ Standard error of the mean.

On the other hand, samples collected from lowest was recorded in Baibirang $(750 \mathrm{~g} / \mathrm{kg})$. traders show maximum (by weight) proportion of Baibirang $(100 \mathrm{~g} / \mathrm{kg})$ was recorded most best quality roots $(905 \mathrm{~g} / \mathrm{kg})$ in Bach species adulterated species, followed by Aonla $(95 \mathrm{~g} / \mathrm{kg})$. followed by Ashwagandha $(800 \mathrm{~g} / \mathrm{kg})$ whereas, Maximum infected tubers were found in the 
samples of safed musli $(80 \mathrm{~g} / \mathrm{kg})$ whereas lowest in Bach $(7 \mathrm{~g} / \mathrm{kg})$. The proportion of chaff matter was recorded more in Aonla samples (110 g/kg) followed by Baibidang ( $80 \mathrm{~g} / \mathrm{kg})$, whereas least in Bach (10 g/kg).

During the analysis of samples of Ashwagandha roots collected from Nagpur market it was observed that mixing of Nagouri asgandh (thick, inferior and cheap variety of Asgandh) was rampant (Table 3). Intentional mixing of lateral thin roots of same species by primary collectors was also noted in the market samples. Similarly, in case of Aonla (dry) fruits primary collectors mix seed/stone and old stocked fruits (Table 3). The adulterants found in the market sample of Aonla were- broken parts of Harra ( $T$. chebula) and Bahera (T. bellerica) fruits etc. The primary collector usually collects immature and small sized fruits from the nearby forests which also contain stone/seed part and soil, etc. On the other hand traders and middleman adopted malpractices like imbibing small and immature Aonla fruits in salt water. This makes the taste of fruit (immature) sour, a marker of good quality fruits.

The actual Safed musli commercially traded is Chlorophytum borivilianum. Due to extensive collection from wild areas, it has now become less available. Due to market demand it is also cultivated. But in case of market samples of safed musli, it was observed that primary collectors mix similar looking species like $C$. tuberosum, $C$. arundinaceum, etc. The traders and middlemen also mix diseased musli, chaff matter, etc. to increase the weight. On the other hand, entirely different species "Kulanjan"(Alpinia galanga Linn.) was sold as Bach. Few traders were found selling completely different but similar look like species A. galanga in the name of Bach in the Nagpur market.

Table 3. Adulterants present in the market samples and malpractices adopted by collectors, traders, etc. of Nagpur district.

\begin{tabular}{|c|c|c|c|c|}
\hline Medicinal plants & $\begin{array}{l}\text { Problem of mis- } \\
\text { identification of } \\
\text { spp. if any }\end{array}$ & $\begin{array}{c}\text { Adulterants } \\
\text { found in the } \\
\text { market samples }\end{array}$ & $\begin{array}{c}\text { Malpractices } \\
\text { adopted by } \\
\text { primary collectors }\end{array}$ & $\begin{array}{c}\text { Malpractices } \\
\text { adopted by } \\
\text { Traders (after } \\
\text { collection) }\end{array}$ \\
\hline Ashwagandha (Withania somnifera) & No & Nagauri asgandh & $\begin{array}{l}\text { Lateral roots of } \\
\text { asgandh }\end{array}$ & $\begin{array}{l}\text { Mixing of Nagouri } \\
\text { asgandh }\end{array}$ \\
\hline Aonla (Emblica officinalis) & No & $\begin{array}{l}\text { Broken parts of } \\
\text { Harra }(T . \text { chebula) } \\
\text { and Bahera ( } T . \\
\text { bellerica) fruits }\end{array}$ & $\begin{array}{l}\text { Harvesting of } \\
\text { immature fruits, } \\
\text { diseased fruits etc. } \\
\text { Stone/ seed intact } \\
\text { with fruits }\end{array}$ & $\begin{array}{l}\text { Imbibing fruits in } \\
\text { salt water }\end{array}$ \\
\hline *Safed musli (Cholorphytum spp.) & Yes & $\begin{array}{l}\text { C. tuberosum. } \\
\text { C. arundinaceum }\end{array}$ & $\begin{array}{l}\text { Mixing of diseased } \\
\text { musli, Chaff matter, } \\
\text { soil, etc. }\end{array}$ & $\begin{array}{l}\text { Mixing of other spp. } \\
\text { of safed musli. } \\
\text { imbibing in lime. }\end{array}$ \\
\hline Bach (Acorus calamus) & Yes & $\begin{array}{l}\text { Kulanjan, old } \\
\text { roots of Bach }\end{array}$ & Early harvesting & $\begin{array}{l}\text { Mixing of roots } \\
\text { Alpinia galanga, } \\
\text { decayed roots }\end{array}$ \\
\hline Baibidang (Embelia ribes) & No & $\begin{array}{l}\text { Poi (Vegetable) } \\
\text { fruits, papaya, } \\
\text { Lantana seeds }\end{array}$ & Nil & $\begin{array}{l}\text { Mixing Poi (Basella } \\
\text { rubra) fruits. } \\
\text { Papaya seeds }\end{array}$ \\
\hline
\end{tabular}

*Mixed tubers of Chlorophytum borivilianum, C. tuberosum 
Sample analysis of Baibidang shows that traders as well as collectors mix Poi fruits (Basella rubra L.) as adulterants, which are similar in appearance and growing in the back yards of most of the villages as vegetable or as weed. Fruits were collected at unripe or green stage. Broken fruits of the same species were generally mixed along with chaff matter to increase the volume. Moreover, few market traders adopt malpractices like imbibing seeds in black color for $24 \mathrm{~h}$.

\section{DISCUSSION}

\section{Current harvesting practices}

The immature extraction of fruits, roots, tubers, etc. has drastically reduce the quality of the raw product below the critical level. Scientists (Mishra et al. 2002; Prasad et al. 2002; Mishra and Kotwal, 2003, 2004, 2007) conducted a number of studies on sustainable harvesting, value addition, processing of some important medicinal plants of central India, viz. Aonla (E. officinalis), Achar ( $B$. lanzan), Bel (A. marmelos), Safed musli ( $C$. borivillianum), Satawar (A. racemosus) Kali haldi (C. caesia), Sarpgandha (R. serpentina), Baichandi (Dioscorea daemona), etc. and reported that due to immature extraction the yield per plant and quality of raw material of these species were declining in the natural forests. Other factors responsible are competition among collectors to collect as much as, unripe harvesting, high price of product in the market, etc. Further, they suggested that the collection before maturation should not be permitted so as to maintain quality of raw materials.

Ayurvedic industries also procure immature fruits, tubers. Mishra et al. (2003) studied ecological status and impact of harvesting of Aonla, Achar, Bel fruits and Siali leaves (Bauhinia vahlii Wight and Arn.) in the three districts of Orissa state. They suggest that proper training in scientific collection techniques, lack of knowledge about proper time of harvesting and unhealthy competition among collectors are some of the reasons leading to unsustainable harvesting of wild fruits, roots, etc.

\section{Market sample analysis}

Sample analysis shows that not only traders but collectors also mix similar looking fruits of a vegetable species "Poi" (B. rubra). On the other hand middlemen and traders also adopted malpractices like imbibing of seeds in black color solutions etc, as the original color is blackish green which fetches more prices in the market. Rawat et al. (1996) and Rawat (2005) observed that in herbal markets of the country, not only the various species of particular genus but entirely different taxa are being sold under the same vernacular name. Similarly, Bratati and Dutta (1990) and Mitra and Kannan (2007), also reported that adulterations and substitutions are common in trade of herbal raw materials. They quoted example of Bhui amla substituted with Phyllanthus spp. and Nagakesar (Mesua ferrea) market samples adulterated with flowers of Calophyllum inophyllum.

The present paper concludes some measures to prevent adulteration in raw (dry) medicinal plant in the market. The harvesting levels and the sustainable harvesting practices should be known before initiating wild collection. Sustainable harvesting practices should be inserted in the Good Collection Practices (GCP) as part of Working Plan.

\section{ACKNOWLEDGEMENTS}

The authors are thankful to the Divisional Forest Officers (DFOs) and field staff of forest department of Nagpur Forest Divisions for providing field facilities and valuable suggestions. We are also thankful to the Director, Dr. D. K. Bandyopadhaya for his kind inspiration. 


\section{REFERENCES}

Accum, M,F. 1820. A treaties on adulterations of food and culinary poisons. A.B.M. Small, Philadelphia, USA.

Brataiti, D.E. and P.C. Dutta. 1990. Pharmacognostic evaluation of Phyllanthus amarus. International Journal of Crude Drug Research. 28(2):91-88.

Dubey, N.K., R. Kumar and P. Tripathi. 2004. Global promotion of herbal medicine: India's opportunity. Current Science. 86(1):37-41.

Gupta, A.K., S.K. Vats and B. Lal. 2003. How cheap can a medicinal plant be? Current Science. 84:565-556.

Handa, S.S. 2004. Indian efforts for quality control and standardization of herbal drugs/products. Proceedings of the $1^{\text {st }}$ Joint Workshop on Quality Control and Standardization of Traditional Medicine-Indo-China experience; Jan 8-10, 2004.

Lange, D. 2004. Medicinal and aromatic plants: trade, production, and management of botanical resources. In: Medicinal and Aromatic Plants $R$ and D. (eds.) Cracker, L.E. and J.E. Simon. Rte des Lucioles, F-06901 Sophia Antipolis, France.

Mishra, M. 2000. Harvesting practices and management of two critically endangered medicinal plants in the natural forests of central India. Proceedings of the International Seminar on Harvesting of Non Wood Forest Products, Menemen-Izmir, Turkey, Oct. 2-8, 2000. pp. 335-341.

Mishra, M. and P.C. Kotwal. 2003. Sustainable management of some critically endangered species of medicinal plants in central India. Project report submitted to Indian Institute of Forest Management. Bhopal, India.
Mishra, M. and P.C. Kotwal. 2004. Ecological status of rare and important medicinal plant Kali musli (Curculigo orchioides) in the tropical forests of central India. Vaniki Sandesh. 28(2 and 3): 16-23.

Mishra, M. and P.C. Kotwal. 2007. Harvesting decline and economics of Baichandi (Dioscorea daemona) in the natural forests of central India. Flora and Fauna. An International Research Journal, 13(2):243248.

Mishra, M., S. Teki and R.P. Mishra. 2003. Sustainable harvesting, value addition and marketing of selected non timber forest products: A case study of Koraput, Malkangiri Districts, Orissa. Project report submitted to RCNEAB, Regional center, Indian Institute of Forest Management, Bhopal (M.P), India.

Mitra, S.K. and R. Kannan. 2007. A note on unintentional adulterations in Ayurvedic herbs. $\mathrm{R}$ and $\mathrm{D}$ Center, The Himalaya Drug Company, Bangalore-562123. India. www.siu.edu/ ebl/leaflets/kannan.htm

Prasad, R., P.C. Kotwal and M. Mishra. 2002. Harvesting practices of Safed musli (Chlorophytum spp.) and its ecological impact on the natural forests of central India. Journal of Tropical Forestry. 18(1):9-24.

Rawat, A.K.S. 2005. Importance of quality control of raw material in Ayurvedic medicine. In: Herbal Medicine Phytopharmaceuticals and Other Natural Products: Trends and Advances. Jointly publ. by Centre for $\mathrm{S}$ and $\mathrm{T}$ of NAM and other countries and Institute of Chemistry, Ceylon, Sri Lanka.

Rawat, A.K.S., A.S. Mehrotra and U. Shome. 1996. Comparative pharmacgnostic studies of Abies spectabilis and Taxus wallichiana. 
International Journal of Pharmacognosy, 34(5):378-383.

Saraswathy, A. 2001. Adulterants and substitutes in Ayurveda. Sachitra Ayurved. 54(1):63-66.

Sarin,Y.K. 1996. Illustrated manual of herbal drugs used in Ayurveda. CSIR and ICMR, Niscom, New Delhi.

Sarin,Y.K. 2003. Medicinal plant raw materials for Indian drug and pharmaceutical industry I. An appraisal of resources. Indian Forester. 129(1):3-24 .

Sunita,G. 1992. Substitute and Adulterant Plants. Periodical Experts Book Agency, New Delhi.
Tewari, N.N. 1991. Some crude drugs: source, substitute and adulterant with special reference to Kathmandu crude drug market. Sachitra Ayurved, 44(4):284-290.

Uniyal, M.R. and G.C. Joshi. 1993. Historical view of the basic principales of the identification of controversial drugs, problems and suggestions. Sachitra Ayurved. 45(7):531-536.

Vasudevan, N., K.R. Yoganarasimhan, M. Kehava and T.R. Shantha. 1983. Studies on some south Indian market samples of Ayurvedic drugs II. Ancient Science of Life, 3(2):60-66. 